\title{
Yield and Quality of the Fetească albă Cultivar in Lechința Vineyard
}

\author{
Claudiu-Ioan BUNEA ${ }^{1 *}$ \\ ${ }^{1)}$ Faculty of Horticulture, University of Agricultural Sciences and Veterinary Medicine, 3-5 Manastur \\ Street, 400372, Cluj-Napoca, Romania. \\ ${ }^{*}$ Coresponding author, e-mail: claus_bunea@yahoo.com
}

Bulletin UASVM Horticulture 71(2) / 2014

Print ISSN 1843-5254, Electronic ISSN 1843-5394

DOI:10.15835/buasvmcn-hort:10450

\begin{abstract}
Yield and the main qualitative characteristics of the 'Fetească albă' cultivar from the Lechința vineyard are presented in this paper in comparison with other four cultivars: 'Fetească regală', 'Chasselas doré', 'Riesling italian' and 'Muscat Ottonel'. All varieties were analysed in the same eco-climatic conditions and were applied the same technology specific to the vine culture. The data were collected and processed on the variants and repetitions. The results have shown that 'Fetească regală' ( $\left.3.8 \mathrm{~g} / \mathrm{l} \mathrm{H}_{2} \mathrm{SO}_{4}\right)$ and 'Chasselas doré' $\left(4.0 \mathrm{~g} / \mathrm{l} \mathrm{H}_{2} \mathrm{SO}_{4}\right)$ recorded the highest values for acidity, $\mathrm{pH}$ was highest at 'Fetească regală' and 'Muscat Ottonel' and cultivar 'Fetească regală' accumulated the largest quantity of sugar $(225.8 \mathrm{~g} / \mathrm{l})$. The highest grape production was recorded for 'Chasselas doré' (8.0 t/ha) and the lowest 'Fetească albă' and'Muscat Ottonel' each other with 5.0 t/ha.
\end{abstract}

Keywords: elements of quality, yield, Vitis vinifera grapes, Lechința vineyard, Fetească albă

Introduction. The quality of the grape harvest is an indicator that varies depending on the cultivar, climate conditions, area of culture and the agrofitotehnic technology applied. The qualitative differentiation of yields are based on sensory, morphological and biochemical criteria (Oprea, 2001). Grapes contain a wide range of chemical substances (sugar, organic acids, vitamins) and also phytochemicals which are responsible for the sensory characteristics of wines (Waterhouse, 2002). The two biochemical components (sugar and acidity) are particularly important in terms of the report sugar/acidity which decisively influences the taste of the grapes (Sestraş, 2004).

Aims and objectives. The aim of this study is to analized the main qualitative characteristics and yield of the 'Fetească albă' cultivar in comparison with other four winegrape cultivars.

Materials and methods. The studies and the research were made (2012) in the experimental field located in viticulture center Vermes, Lechința vineyard. Five cultivars were observed: 'Fetească albă,' 'Fetească regală', 'Chasselas doré',
'Riesling italian' and 'Muscat Ottonel'. The data were collected and processed on the variants and repetitions $(n=3)$. In order to determine the significant differences between values, analysis of variance (ANOVA) and Duncan multiple range tests (MRT) were performed. Significance of difference was defined at the $5 \%$ level $(p<0.05)$. Out of the methods known for sugars determinations within the must it was used the refractometric one. The results are expressed in g/l. Titration in the presence on phenolphthalein was used to determine the total acidity within the must. The acidity is expressed in $\mathrm{g} / \mathrm{l}_{2} \mathrm{SO}_{4}$ and yield in $\mathrm{t} /$ ha. Determination of $\mathrm{pH}$ in must was made with electronic $\mathrm{pH}$ meter.

Results and Discussion. In table 1 are presented the results regarding the following characters: weight of 100 berries, pH, acidity and accumulated sugar. It can observe that the 'Chasselas doré' has recorded the highest value for weight of 100 berries (221.3 g), the pH was highest for 'Fetească albă' (3.8), 'Muscat Ottonel' has accumulated the largest amount of sugar 
Tab. 1. The main qualitative parameters of grapes, Lechința, 2012

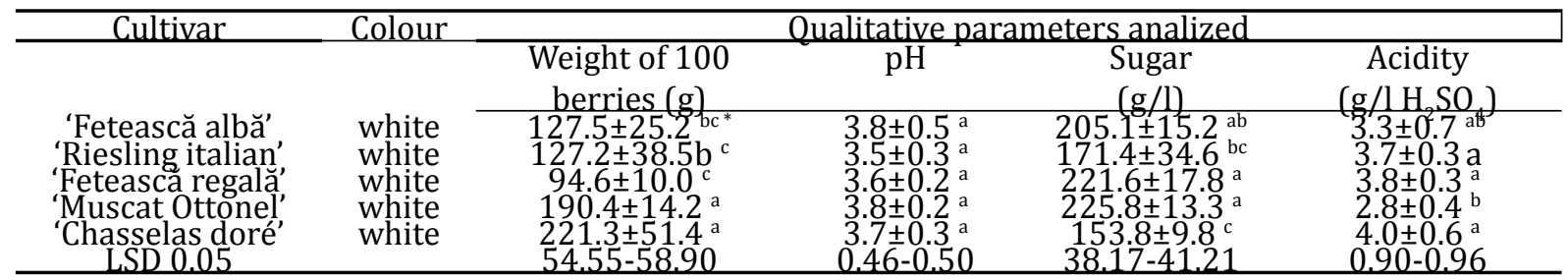

Values are mean $\pm S D, n=3$; in each column, mean values with different letters are significantly different at $p<0.05$

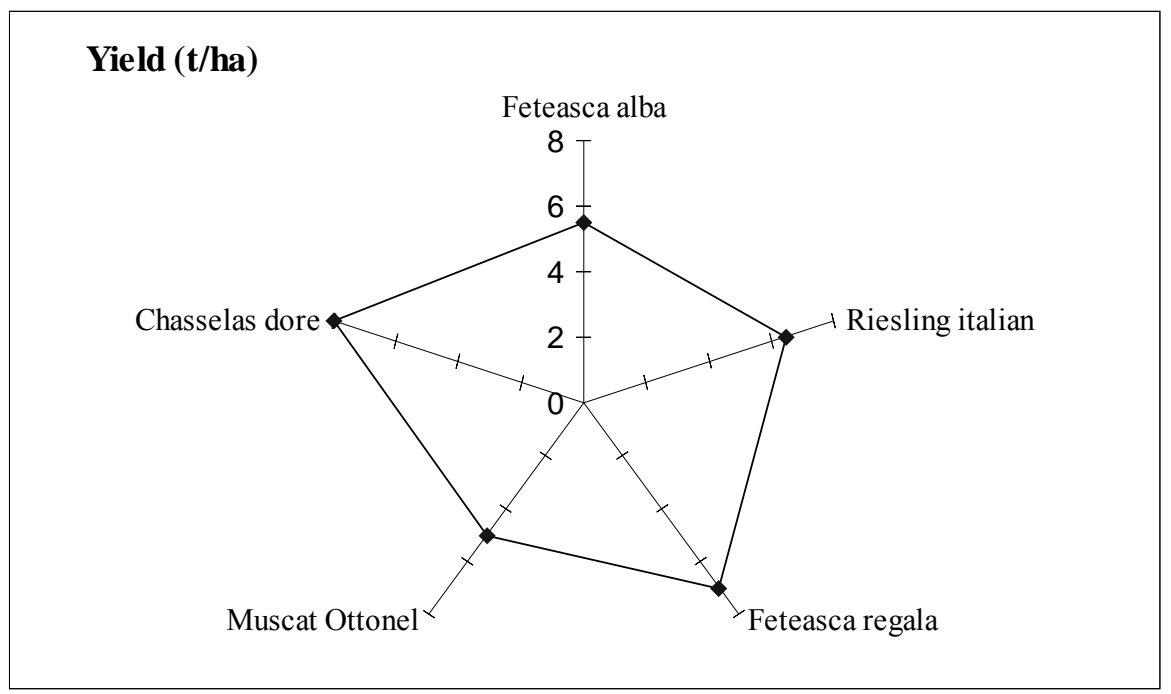

Fig. 1. Yield of five wine grape cultivars, Lechința, 2012

$(225.8 \mathrm{~g} / \mathrm{l})$ and the largest value for acidity it has obtained by 'Chasselas doré' cultivar $(4.0 \mathrm{~g} / \mathrm{l}$ $\mathrm{H}_{2} \mathrm{SO}_{4}$ ).

'Chasselas doré' has recorded the highest value for yield $8.0 \mathrm{t} / \mathrm{ha}$, follow at significant differences by 'Fetească regală' (Figure 1). 'Fetească albă' (5.5 t/ha) and 'Muscat Ottonel'(5.0 t/ha) recorded the lowest results concerning grape production. All results are in agreement with other literature data (Rotaru, 2009; Bunea et al., 2013)

Conclusion. Even if 'Fetească albă' is considered, by tradition, the representative cultivar of Lechința, in eco-climatic conditions of 2012, yield and quality, have not been positive values compared with other four varieties tested. Grape productions are lower than normal due to the loss of buds in winter and the drought from 2012.

\section{REFERENCES}

1. Bunea CI, Popescu D, Bunea A and Ardelean M (2013). Variation of attack degree of downy mildew (Plasmopara viticola) in five wine grape varieties, under conventional and organic control treatments, Journal of Food, Agriculture \& Environment Vol.11 (3\&4):1166-1170

2. Oprea Şt (2001). Viticultura. Ed. AcademicPres. ClujNapoca

3. Rotaru L (2009). Soiuri de viţă de vie pentru struguri de vin. Ed."Ion Ionescu de la Brad", Iaşi

4. Sestraş R (2004). Ameliorarea speciilor horticole. Editura AcademicPres. Cluj-Napoca

5. Waterhouse AL (2002). Wine phenolics. Annals of The New York Academy of Sciences.957:21-36 